Nikolina Antonić - Kyra Lyublyanovics

\title{
PRILOG PROUČAVANJU GOSPODARSTVA I PREHRAMBENIH NAVIKA U TUROPOLJU U 13. STOLJEĆU - ŽIVOTINJSKI OSTACI S NALAZIŠTA KOBILIĆ $1^{*}$
}

Nikolina Antonić

Novomarofska 43, Zagreb

Kyra Lyublyanovics

Department of Medieval Studies,

Central European University, Budapest

\author{
UDK 903-35(497.5-3Turopolje)"12" \\ [308+338] (497.5-3Turopolje)"12" \\ Izvorni znanstveni rad \\ Primljeno: 17.6.2015. \\ Prihvaćeno: 14.12.2016. \\ DOI: http://doi.org/10.21857/mwo1vc5dly
}

$U$ radu se pokušava dati novi pogled na problematiku ekonomske baze turopoljskog sitnog plemstva u 13. stoljeću. $U$ analizu su uključene dvije vrste izvora - pisani izvori te faunalni ostataci sakupljeni tijekom arheološkog istraživanja na nalazištu Kobilić 1. lako brojčano mali te time i nedovoljni za donošenje većih zaključaka, ovi nalazi ipak ukazuju na određene aktivnosti koje nisu spomenute u povijesnim izvorima. Kombinacija obje vrste izvora donosi, iako fragmentarne, potpunije spoznaje o ekonomskoj podlozi i svakodnevnom životu u srednjovjekovnom turopoljskom selu.

Ključne riječi: Turopolje, razvijeni srednji vijek, arheološko nalazište Kobilić 1, arheozoologija, ekonomska povijest, svakodnevni život, srednjovjekovno selo

\section{Uvod}

U proučavanju srednjovjekovne povijesti određenog područja, važan dio pripada proučavanju ekonomske podloge određenih društvenih skupina. No, što su stoljeća srednjega vijeka ranija, pisanih je izvora manje, pa je samim time i proučavanje teže. Tu ključna uloga pripada arheologiji. Iako je priroda arheoloških i povijesnih

\footnotetext{
* Zahvaljujemo dr. Alice Choyke s Odsjeka za srednjovjekovne studije, Srednjoeuropsko sveučilište u Budimpešti (Department of Medieval Studies, Central European University, Budapest) za pomoć i savjete kojima nam je pomogla tijekom pisanja ovog članka. Također, zahvaljujemo Dženi Los (Kaducej d.o.o.), voditeljici istraživanja arheoloških radova na nalazištu Kobilić 1 , na ustupanju materijala srednjovjekovnog horizonta na obradu.
} 
Nikolina Antonić - Kyra Lyublyanovics: Prilog proučavanju gospodarstva i prehrambenih navika... Zb. Odsjeka povij. znan. Zavoda povij. druš. znan. Hrvat. akad. znan. umjet., 34 (2016), str. 21-37

izvora različita, kombinacija dvije vrste izvora dovodi do boljeg razumijevanja srednjovjekovne svakodnevice te istovremeno otvara brojna nova pitanja. U ovom član$\mathrm{ku}$, želimo ukazati na, u hrvatskoj medievistici još uvijek nedovoljno iskorištenu, vrijednost arheoloških istraživanja srednjovjekovnih sela. Kao primjer poslužit će specifična vrsta arheoloških izvora - ostaci životinjskih kostiju s nalazišta Kobilić 1. Odmah na početku treba naglasiti da je sam broj kostiju sakupljenih tijekom istraživanja premali za donošenje bilo kakvih konkretnih statističkih zaključaka i dalekosežnih hipoteza. No, i mali broj podataka ima određenu vrijednost u kontekstu određenog prostora. Štoviše, budući da se u ovom slučaju radi o Turopolju, području poznatom po velikom broju sačuvanih povijesnih izvora, moguće je sagledati na konkretnom primjeru kakve informacije donose arheološki, a kakve povijesni izvori. Uz to, kao što će biti prikazano u ovom tekstu, samo nalazište Kobilić 1 teško je interpretirati i arheološki (što je nađeno, rub sela ili manjeg posjeda) i povijesno (kojoj društvenoj skupini pripadaju istraženi ostaci). Samim time, sakupljani podatci su nedovoljni za konkretnu interpretaciju, ali mogu poslužiti kao primjer teškoća s kojima se susrećemo $u$ istraživanju ovake i sličnih tematika.

Nakon par uvodnih riječi o Turopolju, uz pregled prijašnje historiografije i izvora, te pregled dosadašnjih arheozooloških istraživanja srednjovjekovnih nalazišta na prostoru sjeverne Hrvatske, tadašnje srednjovjekovne Slavonije, razmotrit će se podatci iz povijesnih a nakon toga i arheozooloških izvora vezanih uz nalazište Kobilić 1 .

\section{Turopolje - pregled izvora i literature}

Turopolje je bilo predmetom znanstvenog istraživanja pravnih ${ }^{1}$ i društvenih povjesničara. ${ }^{2}$ Jedini koji se dotakao pitanja ekonomske povijesti ovog kraja je bio

Aleksandar Bresztyenszky, Pravno-povijesni podatci o Turopolju, Zagreb 1892.; Magdalena ApostolovaMaršavelski, Quarta puellaris po običajom pravu Turopolja (13.-16. st.), Zbornik pravnog fakulteta u Zagrebu, god. 42, br. 2, Zagreb 1992., str. 141-149.

2 Najviše su se istražile povijesti određenih obitelji u Turopolju, posebice od početka 21. stoljeća. Usp.: Ivan Jurković, Raseljena plemićka obitelj za osmanske ugroze: primjer Berislavića de Werhreka de Mala Mlaka (Dio prvi - Stjepan Berislavić Vrhrički i Malomlački), Zbornik Odsjeka za povijesne znanosti Zavoda za društvene i povijesne znanosti Hrvatske akademije znanosti i umjetnosti (dalje: Zbornik OPZ ZPDZ $H A Z U)$, sv. 20, Zagreb 2002., str. 125-164; Isti, Raseljena plemićka obitelj za osmanske ugroze: primjer Berislavića de Werhreka de Mala Mlaka (Dio drugi - Nasljednici Stjepana Berislavića tijekom 16. st.), Zbornik OPZ ZPDZ HAZU, sv. 21, Zagreb 2003., str. 119-181; Suzana Miljan, Plemićka obitelj Krupić iz Velike Mlake u 15. i 16. stoljeću, Zbornik OPZ ZPDZ HAZU, sv. 29, Zagreb 2011., str. 83-125; Ista, Nijemci u Turopolju u kasnom srednjem vijeku, Godišnjak njemačke zajednice. DG Jarhbuch, sv. 18, Osijek 2011., str. 29-50; Marija Karbić, Plemićka obitelj Mikšić iz roda Levča do početka 16. stoljeća, Zbornik OPZ ZPDZ HAZU, sv. 32, Zagreb 2014., str. 67-78. Još su neki autori istraživali povijest Turopolja na komparativan način, primjerice: Marija Karbić, Heiratsstrategien des Kleinadels von Turopolje (Slawonien) im späten Mittelalter, East Central Europe, god. 29, br. 1-2, Budapest 2002., str. 167-176; Gábor Szeberény, Noble Communities in Spiš and Turopolje in the Thirteenth and Fourteenth Centuries, u: Slovakia and Croatia: Historical Parallels and Connections (until 1780), Slovakia and Croatia, sv. ur. Martin Homza - Ján Lukačka - Neven Budak, Bratislava 2013., str. 222-227; Tatiana Hutyrová - Neven Budak, A comparison of the privileged communities Campus Zagrabiensis and Parvus comitatus, u: Slovakia and Croatia, str. 227-231. 
Nikolina Antonić - Kyra Lyublyanovics: Prilog proučavanju gospodarstva i prehrambenih navika... Zb. Odsjeka povij. znan. Zavoda povij. druš. znan. Hrvat. akad. znan. umjet., 34 (2016), str. 21-37

Josip Adamček u svom djelu Agrarni odnosi u Hrvatskoj od sredini XV do kraja XVII stoljeća. Kao što sam naslov njegova djela govori, ono obuhvaća period od sredine 15. do kraja 18. stoljeća, dakle razdoblje kada se istraživanje može temeljiti na sačuvanim poreznim spisima. No, treba naglasiti da Adamček spominje i prve isprave 13. stoljeća vezane uz svinjogojstvo. ${ }^{3}$ Važan aspekt za našu temu - pitanje vlasništva nad zemljom - obradili su Emilij Laszowski i Marija Karbić. ${ }^{4}$ Laszowski se ujedno, u svojoj Povijest plemenite općine Turopolje nekoč Zagrebačko polje zvane dotakao i razvoja sela Kobilić, Rakarije i Velika Gorica, o kojima će ovdje biti riječi. ${ }^{5}$ Stanje u Zagrebačkoj županiji u 13. stoljeću, a time naravno i u Turopolju, obradila je Nada Klaić u Povijesti Zagreba te djelomično i u Povijesti Hrvata u razvijenom srednjem vijeku. ${ }^{6} \mathrm{U}$ sklopu svog djela o posjedima Templara i Ivanovaca u Hrvatskoj, Lelja Dobronić spominje i posjede potonjih u Turopolju. ${ }^{7}$ Isto tako, u sklopu svojeg istraživanja o posjedima Zagrebačkog kaptola, Radovan Gajer se dotakao i kaptolskih posjeda u Turopolju. No budući da je ova, kako ju je on nazvao, “južna skupina posjeda" bila i najmanja, dotakao je se sporadično. Ipak, njegova studija, koja obuhvaća analizu funkcioniranja kaptolskih posjeda općenito, važna je i za razumijevanje odnosa na ovom području. ${ }^{8}$

Glavni povijesni izvor za istraživanje Turopolja objavio naslovom Povjesni spomenici plemenite općine Turopolja nekoć "Zagrebačko polje" zvane objavio je Emilije Laszowski. ${ }^{9}$

Arheološka istraživanja u Turopolju intenzivirala su se izgradnjom autoceste Zagreb - Sisak te obilaznica. Naseobinska nalazišta srednjovjekovnog perioda

Josip Adamček, Agrarni odnosi u Hrvatskoj od sredine XV do kraja XVII stoljeća, Zagreb 1980.

Emilij Laszowski, Povijest plemenite općine Turopolje nekoć Zagrebačko polje zvane, 2 sv., Zagreb 1910.1911., sv. 2, str. 101-102; Marija Karbić, Property Relations and Family Structure of the Nobility in the Sava and Drava interamnium in the Middle Ages, u: Slovakia and Croatia, str. 240-242.

5 Laszowski, Povijest plemenite općine, str. 338-340, 380-382, 390-398.

6 Nada Klaić, Povijest Zagreba, kn. 1, Zagreb 1982., str. 24-28, 55-71; Ista, Povijest Hrvata u razvijenom srednjem vijeku, Zagreb 1976., str. 253-313.

7 Lelja Dobronić, Templari i Ivanovci u Hrvatskoj, Zagreb 2002., str. 231-233.

8 Radovan Gajer, Posjedi Zagrebačkog kaptola oko Zagreba u prvoj polovici 14. st., Radovi Zavoda za hrvatsku povijest, sv. 11, br. 1, Zagreb 1978., str. 5-102.

9 Povjesni spomenici plemenite općine Turopolja nekoć "Zagrebačko polje" zvane. Monumenta historica nobilis communitatis Turopolje olim “Campus Zagrabiensis" dictae (dalje: MHNC), sv. 1-4, prir. Emilij Laszowski, Zagreb 1904.-1908. 
Nikolina Antonić - Kyra Lyublyanovics: Prilog proučavanju gospodarstva i prehrambenih navika... Zb. Odsjeka povij. znan. Zavoda povij. druš. znan. Hrvat. akad. znan. umjet., 34 (2016), str. 21-37

istražena su na dva veća lokaliteta: Šepkovčica ${ }^{10}$ i Okuje, ${ }^{11}$ te nekoliko manjih; Mrkopolje, ${ }^{12}$ Buzin, ${ }^{13}$ Kobilić 1 i 2, ${ }^{14}$ itd.

Nalazište Kobilić 1 istraženo je u sklopu zaštitnih arheoloških istraživanja na trasi Obilaznice Velika Gorica, II faza na D 31 sa spojem D 408. Lokalitet je smješten na zapadnom rubu današnjeg naselje Kobilić. ${ }^{15}$ Istraživanjima je obuhvaćen rub srednjovjekovnog naselja ili posjeda, a istražena je 41 arheološka struktura (radni objekti, otpadne jame, jame nepoznate namjene, jarak, nekoliko rupa od stupova). Na osnovi dva rezultata radiokarbonske analize te općih karakteristika pokretnog arheološkog materijala, nalazište je datirano u širok raspon 13. stoljeća. Istražena površina bila je premala za donošenje konkretnih zaključaka o tome što je bio ovaj prostor, vjerojatno se radilo o radnom dijelu, no nejasno ostaje je li riječ o rubu većeg naselja ili o manjem privatnom posjedu. Slično tome, analiza povijesnih izvora je pokazala da se ne može utvrditi kojem društvenom sloju su pripadali ostaci nađeni na nalazištu Kobilić 1 . Budući da je to važno i za interpretaciju faunalnih ostataka, ovo će dodatno biti razjašnjeno $u$ daljnjem tekstu. ${ }^{16}$

Štoviše, analiza izvora koji se odnose na nalazište Kobilić 1 dobar je pokazatelj koliko oprezni trebamo biti u pripisivanju ostataka (ne samo faunalnih, nego i svih ostalih) nekog nalazišta određenoj društvenoj skupini. Kobilić se prvi puta spominje 1424., kao nadimak tj. prezime porodice Vuković iz Velike Gorice. ${ }^{17}$ Prema mišljenju Emilija Laszowskog: "Po ovoj porodici koja se je tamo u to do-

10 Aleksandra Bugar, Naselje ranog srednjeg vijeka Velika Gorica-Šepkovčica, u: Zbornik Srednji vek. Arheološke raziskave med Jadranskim morjem in Panonsko nižino, ur. Mitija Guštin, Ljubljana 2008., str. 179-193; Nikolina Antonić, Late medieval village in Turopolje (Slavonia). The example of Donja Lomnica, u: Secular Power and Sacral Authority in Medieval East-Central Europe, ur. Kosana Jovanović Suzana Miljan, Amsterdam 2017. (u tisku).

11 Aleksandra Bugar, Preliminarno izvješće - rezultati arheoloških zaštitnih istraživanja na lokalitetima Okuje (I, Ia, II, IIa, IIIb) i Mraclinska Dubrava. Muzej grada Zagreba. Autocesta Zagreb - Sisak / koridor A11, dionica Velika Gorica jug - Lekenik, Zagreb 2010.; Ista, Arheometrijske analize i njihova primjena u arheološkoj interpretaciji na primjeru lokaliteta Okuje, Hrvatski arheološki godišnjak, sv. 8, Zagreb 2011. (u tisku); Josip Burmaz - Nikša Vujović, Lokalitet: Okuje III, III a i III c, Hrvatski arheološki godišnjak, sv. 6, Zagreb 2009., str. 243-246.

12 Ina Miloglav - Dino Demicheli, Lokalitet: Mrkopolje, Hrvatski arheološki godišnjak, sv. 6, Zagreb 2009. str. 239-243.

13 Ivan Radman-Livaja - Miljenka Galić - Ljubica Perinić, Istraživanje arheološkog lokaliteta Buzin 2008 godine: pregledni osvrt, Vjesnik arheološkog muzeja u Zagrebu, god. 44, br. 1, Zagreb 2011., str. 261-274.

14 Dženi Los, Lokalitet: AB1 Kobilić 1, Hrvatski arheološki godišnjak, sv. 8, Zagreb 2011. (u tisku).

15 Istraživanje je provela tvrtka "Kaducej" u periodu od rujna do prosinca 2010., te u travnju 2011.; istraživanja su rezultirala naseobinskim nalazima iz prapovijesnog, antičkog i srednjovjekovnog perioda.

16 Osnovni podatci o lokalitetu, s detaljnom objavom izabranih struktura te analizom dva značajna nalaza (lonca s narebrenim vratom i noža napravljenog u tehnici pattern-welding) te detaljna analiza povijesnih izvora i kartografskih izvora o mogućoj pripadnosti naselja u 13. stoljeću objavljena je u članku: Nikolina Antonić - Tibor Ákos Rácz, Selected medieval finds from the Site Kobilić 1 in Turopolje, u: Srednjovjekovna naselja u svjetlu arheoloških izvora. Zbornik Instituta za arheologiju, sv. 6, ur. Tajana Sekelj Ivančan - Tatjana Tkalčec - Siniša Krznar - Juraj Belaj, Zagreb 2017. (u tisku). Rezultati arheometalurške analize dva noža s nalazišta Kobilić 1 objavljeni su u: Ádám Thiele - Jiř́ Hošek - Nikolina Antonić - Tibor Ákos Rácz, Metallographic examination of two medieval knives from Kobilić (Republic of Croatia), Materials and Manufacturing Processes (u tisku).

17 MHNC 1, str. 189-191. 
Nikolina Antonić - Kyra Lyublyanovics: Prilog proučavanju gospodarstva i prehrambenih navika... Zb. Odsjeka povij. znan. Zavoda povij. druš. znan. Hrvat. akad. znan. umjet., 34 (2016), str. 21-37

ba valjda naselila, prozvano je to naselje, potonje selo Kobilić".${ }^{18}$ Od razdoblja 15. stoljeća selo Kobilić je dio turopoljske općine. Arheološki nalazi očito potvrđuju da je prostor sela bio naseljen i ranije. Ipak, ovo ne mora nužno biti dokaz da je selo Kobilić kao takvo postojalo ranije od 13. stoljeća. Ovaj je prostor mogao biti dio Velike Gorice ${ }^{19}$ ili Rakarija (nekad veće turopoljsko selo, danas dio Velike Gorice) ${ }^{20}$ koji se kasnije razvio u zasebno selo. Dakle, u tom slučaju prostor bi bio u vlasništvu pripadnika turopoljskog sitnog plemstva. No, isto tako, nalazište se nalazi na obali starog potoka Bapče, a selo Bapča, koje se danas nalazi sjeverno od potoka, spominje se 1420. kao praedium koji Ivan Alben, tada gospodar Medvedgrada, daje Ivanu sinu Mihaela iz Patine. ${ }^{21}$ To znači da je u 13. stoljeću prostor Bapče bio najvjerojatnije još uvijek u kraljevskim rukama. Sa druge strane, južno od Kobilića bilo je smješteno Želinsko imanje, prvo pod direktnom upravom slavonskog bana, a od 1293. pod upravom Babonića. ${ }^{22}$

Dakle, iako se može pretpostaviti da je i u 13. stoljeću prostor Kobilića bio vlasništvo turopoljskog sitnog plemstva, to se ne može dokazati, te se i ostale mogućnosti ne mogu isključiti. Uz to, i dalje ostaje pitanje je tko je sve živio u takvom selu. Zasigurno, uz sitne plemiće (iobagiones castri) tu su bili i oni nižeg statusa (iobagioni), odnosno seljaci koji su živjeli na njihovim imanjima o čemu svjedoči isprava iz 1278. kojom ban Nikola utvrđuje prava i dužnosti sitnog plemstva (iobagiones castri) cijele zagrebačke županije. ${ }^{23}$

No, uza sve rečeno, daljnja analiza ipak daje uvid u uzgoj životinja i aktivnosti koje su se odvijale na području Turopolja, a kojih u pisanim dokumentima nema. ${ }^{24}$

18 Laszowski, Povijest plemenite općine, sv. 1, str. 338.

19 Prva isprava koja spominje cestu koja vodi u Goricu (stratam) datira iz 1228. godine. Laszowski je smatrao da se najvjerojatnije radi o Velikoj Gorici. Crkva Blažene djevice Marije spominje se u Popisu Župa iz 1334. godine. Laszowski, Povijest plemenite općine, sv. 1, str. 392.

20 Terra Rakarya spominje se 1278. kao posjed, a ljudi koji žive u Rakarju (de Rakarya) spominju 1393. MHNC 1, str. 31-32, 101-102; Laszowski, Povijest plemenite općine, sv. 1, str. 380.

21 MHNC 1, str. 175-176.

22 CD 7, str. 146-148.

23 .... nullus collectorum iobagiones in curia eorundem iobagionum castri existentes. MHNC 1, str. 31.

24 Kao primjer može se navesti nalazište Muhi u Mađarskoj. Na nalazištu su ustanovljene dvije zone centralna ulica za koju se pretpostavljalo da je nastanjena imućnijim stanovništvom, te rubni dio gdje se je pretpostavljalo da su živjeli ljudi nižeg socijalnog statusa. Iako u količini otpada nije bilo znatnije razlike, istraživanje je pokazalo da suptilne razlike ipak postoje. Dok je na rubovima sela veća zastupljenost svinje i malih preživača (ovca, koza), govedo je u većem broju zastupljeno u centralnom djelu sela. Govedo znači veće količine mesa nego svinja ili ovca/koza, te samim time se dolazi do zaključka da su stanovnici centralne ulice imali pristup većim količinama mesa. Ove su razlike suptilne i tek se trebaju potvrditi daljnjim istraživanjima, ali i ovi prvi rezultati su vrlo zanimljivi. (Usporedbe radi, dok se u slučaju nalazišta Kobilić 1 radi o 407 fragmenta, u ovom istraživanju bila su zastupljena 7834 fragmenta, od kojih je identificirano 5759, za period 12./13. do 13./14. st.) Vidi više u: Kyra Lyublyanovics, Before the cattle trade. Animals and people in Muhi, a medieval Hungarian village, magistarska radnja, Budapest 2008 . 
Nikolina Antonić - Kyra Lyublyanovics: Prilog proučavanju gospodarstva i prehrambenih navika... Zb. Odsjeka povij. znan. Zavoda povij. druš. znan. Hrvat. akad. znan. umjet., 34 (2016), str. 21-37

\section{Arheozoološke analize - komparativan materijal}

Što se Turopolja tiče, trenutačno su analize faunalnih ostataka objavljene za nalazište Buzin (4./5.-9 st.), ${ }^{25}$ te su opći rezultati analize objavljeni u sklopu članaka o naselju na nalazištu Šepkovčica (9./10.-15 st.). ${ }^{26}$

Od ostalih nalazišta na prostoru srednjovjekovne Slavonije objavljeni su rezultati analiza za utvrde Vrbovec, ${ }^{27}$ Cesargrad ${ }^{28}$ i Čanjevo, ${ }^{29}$ te nekoliko gradišta ${ }^{30} \mathrm{i}$ nizinskih naselja. ${ }^{31}$ Dakle, iako se ne može reći da su nalazišta srednjovjekovnog perioda posve zanemarena, rezultata je još uvijek premalo za veće komparacije i donošenje širih zaključaka, pogotovo u pogledu naselja seoskog, nizinskog područja. Ovo naravno ne znači da se već sada ne mogu ponuditi određene komparacije, već da je velika vjerojatnost da će se sadašnje spoznaje mijenjati novim podatcima.

S obzirom na to da je Turopolje kao dio srednjovjekovne Slavonije bilo ne samo dijelom Hrvatsko-Ugarskog Kraljevstva, već je i geografski dio Panonske nizine, zanimljivi su rezultati analiza dobivenih podataka na području današnje Mađarske, te će se i one koristiti kao komparativni materijal. Također, mađarska arheozoološka škola je zanimljiva i u smislu interpretacije arheozooloških izvora u kombinaciji s ostalim vrstama povijesnih izvora, što pridonosi proširivanju općeg znanja o različitim aspektima srednjovjekovlja. U prvom redu tu je i danas referentno djelo Sándora Bökönyia History of Domestic Mammals, ${ }^{32}$ a njegov rad je uspješno nastavilo više istraživača, od kojih se ističe Lászlo Bartosiewicz. ${ }^{33}$

${ }_{25}$ Maja Grgurić, Analiza faune ranosrednjovjekovnog lokaliteta Buzin, Vjesnik arheološkog muzeja u Zagrebu, god. 44, br. 1, str. 329-338.

26 Bugar, Naselje ranog srednjeg vijeka, str. 180

27 Tajana Trbojević-Vukičević - Silvia Frančić - Snježana Kužir, Analiza životinjskih kostiju iz srednjovjekovnog burga Vrbovca u Klenovcu Humskome, u: Burg Vrbovec u Klenovcu Humskome: deset sezona arheoloških istraživanja, prir. Tatjana Tkalčec, Zagreb 2010., str. 234-246.

28 Andrej Janeš, Burg Cesargrad: povijesno-arheološka analiza, Godišnjak Hrvatskog restauratorskog zavoda, sv. 5, Zagreb 2014., str. 44-45.

29 Tajana Trbojević Vukičević - Ana Štilinović, Arheozoološka analiza kostiju s utvrde Čanjevo, u: Utvrda Čanjevo, istraživanja 2003.-2007., prir. Luka Bekić, Visoko 2008., str. 253-259.

30 Snježana Kužir - Tajana Trbojević Vukičević, Životinjski nalazi s arheološkog lokaliteta Torčec Gradić, Podravina: časopis za multidisciplinarna istraživanja, god. 3, br. 6, Samobor - Koprivnica 2004. str. 116-121; Tatjana Tkalčec, Gudovac-gradina 2004., Annales Instituti Archaeologici, god. 1, br. 1, Zagreb 2005., str. 51.

31 Snježana Kužir - Tajana Trbojević-Vukićević - Mario Poletto, Životinjski ostaci sa srednjovjekovnih nalazišta u okolici Torčeca, u: Podravina u ranom srednjem vijeku. Rezultati arheoloških istraživanja ranosrednjovjekovnih nalazišta u Torčecu, prir. Tajana Sekelj-Ivančan, Zagreb 2010., str. 339-371; Tajana Trbojević-Vukičević, Govedo - osnova stočarstva sa lokalitetu Josipovac Punitovački - Veliko Polje I, u: Josipovac Punitovački - Veliko polje I. Zaštitna arheološka istraživanja na trasi autoceste A4. Eneolitičko, brončanodobno i srednjovjekovno naselje, prir. Lea Čataj et al., Zagreb 2009., str. 283.

32 Sandor Bökönyi, History of Domestic Mammals in Central and Eastern Europe, Budapest 1974.

33 Bibliografija ovog autora je obimna. Ovdje samo spominjemo djela koja će se koristiti u daljnjem tekstu: László Bartosiewicz, Animal husbandry and medieval settlement in Hungary - A review, Beiträge zur mittelalterarchäologie in Österreich, sv. 15, 1999., str. 139-155; László Bartosiewicz, László DarócziSzabó - Márta Daróczi-Szabó - Erika Gál - István Kováts - Kyra Lyublyanovics, Animal exploitation in Medieval Hungary, u: Medieval economy of Hungary as reflected by archaeology and material culture, neobjavljeni rukopis, str. 20-47. 
Nikolina Antonić - Kyra Lyublyanovics: Prilog proučavanju gospodarstva i prehrambenih navika... Zb. Odsjeka povij. znan. Zavoda povij. druš. znan. Hrvat. akad. znan. umjet., 34 (2016), str. 21-37

\section{Povijesni izvori 13. stoljeća u Turopolju}

Ako se sagleda posjedovna situacija tijekom 13. stoljeća u Zagrebačkoj županiji u globalu, vidljivo je da je zemlja bila razdijeljena između velikaša, crkve i teritorija na kojem su boravili sitni plemići (iobagiones castri) koji su ujedno i najbrojnije plemićko stanovništvo županije. Naravno, nakon 1242., ondje je bilo i zemljište u vlasništvu slobodnog kraljevskog grada Gradeca. Time je dovršen proces započet još u 12 . stoljeću - Arpadovići dijele zemlju kojoj nisu sposobni samostalno osigurati vojnu obranu, čime moć kralja slabi, a Crkve i velikaša raste. ${ }^{34}$

Turopolje, Zagrebačko polje (Campus Zagrabiensis), kako je nazivano u onovremenim ispravama, zauzima relativno malu površinu, od nekih 600 kvadratnih kilometara, ${ }^{35} \mathrm{~s}$ tim da je i životni prostor i plodno zemljište još manje, jer su velike površine pokrivale šume i močvare. Uz to, južni dio područja zauzimaju Vukomeričke gorice, koje su pogodne za vinogradarstvo. ${ }^{36}$ Najbrojnije plemićko stanovništvo ovog područja bili su svakako iobagiones castri, sitno kondicionalno plemstvo, koje će se s vremenom organizirati u "Plemenitu općinu Turopoljsku". Veliki dio Turopolja bio je u 13. stoljeću pod upravom slavonskog bana odnosno, od 1293. Babonića (organizirano u Želinsko vlastelinstvo). ${ }^{37} \mathrm{U}$ to vrijeme, u Turopolju su bili i posjedi zagrebačkog kaptola te isto tako veliko područje Čičanskog preceptorata ivanovaca.

Funkcioniranje velikaških i crkvenih imanja, kao i onih ivanovaca, pitanja su kojima je u i našoj i stranoj literaturi posvećeno dosta pažnje, te se ta imanja i u Turopolju trebaju promatrati u sklopu prilika na velikaškim i crkvenim imanjima općenito. ${ }^{38}$ No, zanimljivo je reći par riječi o posjedima sitnih plemića, na koje se dokumenti u Povjesnim spomenicima i odnose.

Broj sačuvanih isprava za razdoblje od 1225. do 1300., za razliku od narednih stoljeća, nije velik, riječ je o 35 izvora. ${ }^{39}$ Ovi dokumenti su, uz povlastice kraljeva i banova, uglavnom kupoprodajni dokumenti, isprave o zakupu, sporovi oko granica te isprave o okupaciji određenih posjeda od strane pojedinaca, tj. tužba oštećene strane pred banom ili samim kraljem. Samo su četiri isprave izdane do 1242. (uključujući jednu te godine). Od 1249. broj sačuvanih isprava sve više raste, te se

${ }_{34}$ Klaić, Povijest Zagreba, str. 25-46.

35 Ivan Garaj, Mikroregija Turopolje, Kaj: časopis za književnost, umjetnost $i$ kulturu, sv. 5-6, Zagreb 1974. str. 195.

36 Borna Fürst-Bjeliš, Turopolje, Meridijani, sv. 94, Samobor 2005., str. 52.

37 Codex diplomaticus Regni Croatiae, Dalmatiae et Slavoniae. Diplomatički zbornik Kraljevine Hrvatske, Dalmacije i Slavonije, sv. 7, prir. Tadija Smičiklas, Zagreb 1909., str. 146-148.

38 Za Baboniće, usp.: Hrvoje Kekez, Plemićki rod Babonića do kraja 14. stoljeća, doktorska disertacija, Zagreb 2012., str. 238-247. Za funkcioniranje ivanovačkih preceptorata, vidi: Zsolt Hunyadi, Hospitaller Estate Management in the Medieval Kingdom of Hungary (Thirteenth to Fourteenth Centuries), u: The Military Orders: On land and by sea, ur. Malcolm Barber - Judith Mary Upton-Ward, Aldershot 2008., str. 145-153. Za kaptolske posjede, usp.: Gajer, Posjedi zagrebačkog kaptola, str. 17-23, 56-100.

39 MHNC 1, str. 1-38. 
Nikolina Antonić - Kyra Lyublyanovics: Prilog proučavanju gospodarstva i prehrambenih navika... Zb. Odsjeka povij. znan. Zavoda povij. druš. znan. Hrvat. akad. znan. umjet., 34 (2016), str. 21-37

analiza naravno može preciznije odnositi na drugu polovicu 13. stoljeća. ${ }^{40}$ Ukupan broj pravnih slučajeva o kojima dokumenti svjedoče je manji jer je dosta isprava ponovo potvrđivano pred višom instancom, pa tako detalje možemo saznati o dvadesetak slučajeva.

Unutar pripadnika turopoljskog sitnog plemstva postojalo je više kategorija posjedovanja zemlje; ona je mogla biti vlasništvo pojedinca, vlasništvo obitelji, vlasništvo roda te komunalno vlasništvo (npr. šume). ${ }^{41}$ Kao privatno vlasništvo, zemlja je bila predmet transakcija. Već je iz prve sačuvane kupoprodajne isprave iz Turopolja očito da su prodavači bili i pojedinci te više pojedinaca koji su vlasnici pojedinog zemljišta. Na zagrebački kaptol došao je veći broj ljudi koji su izjavili da su svoje zemlje prodali određenoj osobi P. ${ }^{42}$ Učestalo je bilo i davanje zemlje u zakup uz određenu cijenu. Prvi sačuvani dokumenti ove vrste potječu iz druge polovice stoljeća.

Procesi sve većeg rasta važnosti novca i zamjene naturalne rente novčanom obilježili su 13. stoljeće. ${ }^{43}$ Tako je i turopoljsko sitno plemstvo uključeno u ove tokove. Samo se u spomenutoj kupoprodajnoj ispravi iz 1228. ne navodi cijena zemalja koje su predmet prodaje, a sve ostale isprave sadrže i cijenu. Moneta koja se koristi je zagrebački denar, tj. banovac. Štoviše, prvi spomen zagrebačkog denara baš nalazimo $\mathrm{u}$ jednoj ispravi iz Turopolja. ${ }^{44}$ Volkota i Volkuzlou, sinovi Iurgisa, i Obrad, sin Iurenka, prodaju 1260. Miroslavu 12 vretena zemlje za 15 pensi zagrebačkih denara. ${ }^{45}$

Još je jedna karakteristika 13. stoljeća da je općenito prisutno sve veće okrupnjavanje velikaških i crkvenih posjeda te posjeda bogatijih pojedinaca. ${ }^{46}$ Takve pokušaje nalazimo i u Turopolju, recimo spomenuti comes $P$. No, ono što će ostati karakteristično za ovaj prostor je da zapravo ni u kasnijim stoljećima pravog okrupnjavanja zemlje koja je pripadala turopoljskoj općini neće biti. Naravno, tijekom stoljeća situacija će se mijenjati. Razni velikaši, u razdoblju nakon Žigmundove prodaje Medvedgrada 1398. pa do obnove Turopoljskog bratstva 1560., pokušavat će uspostaviti vlast nad turopoljskim plemićima. ${ }^{47}$ Bit će naravno i pojedinaca unutar plemenite općine koji će željeti i privremeno uspjeti okrupniti svoje posjede. ${ }^{48}$ No, ono što će

40 Ista situacija je tipična i za druge dijelove Ugarskog kraljevstva. Pál Engel, The Realm of St. Stephen. A History of Medieval Hungary, 895-1526, London - New York 2001., str. 122.

${ }_{41}$ Laszowski, Povijest plemenite općine, sv. 2, str. 101-102; Karbić, Property Relations and Family Structure, str. 240-242.

42 MHNC 1, str. 16-17. Comes P., koji se spominje u ispravi ne može se identificirati. Očito se radi o uglednijoj osobi, a termin kojim se oslovljava možda znači je bio nekadašnji župan neke od županija s prve polovice 13. stoljeća.

43 Klaić, Povijest Hrvata, str. 292.

44 Ivan Mirnik, Dobri denar zagrebački, Iseljenički kalendar 1991, Zagreb 1991., str. 170.

45 MHNC 1, str. 3-5.

46 Vidi Klaić, Povijest Hrvata, str. 287-340.

47 Valentina Janković, Borbe turopoljskog plemstva s gospodarima Medvedgrada, Lucius, god. 4-5, Zagreb 2004., str. 101-134.

48 Npr. za pridošlice integrirane u plemenitu općinu koje su u jednom periodu uspjeli stvoriti veće posjede vidi studije: Jurković, Raseljena plemićka obitelj za osmanske ugroze, Dio prvi, str. 125-154 i Raseljena plemićka obitelj za osmanske ugroze, Dio drugi, str. 119-181; Miljan, Plemićka obitelj Krupić, str. 83-125. 
Nikolina Antonić - Kyra Lyublyanovics: Prilog proučavanju gospodarstva i prehrambenih navika... Zb. Odsjeka povij. znan. Zavoda povij. druš. znan. Hrvat. akad. znan. umjet., 34 (2016), str. 21-37

ostati karakteristika Turopolja kroz cijeli srednji vijek i nakon toga, da će se zemlja kupovati, prodavati, parcelirati (dioba među sinovima, djevojačka četvrtina) i između pojedinaca i između rodova (u ovom ranijem periodu) i obitelji, no veleposjedi neće nastati (još jednom treba istaknuti, na prostoru koji je pripadao turopoljskoj općini, za razliku od npr. Želina ili, puno kasnije, Vukovinskog vlastelinstva Alapića). Ovakav tip vlasništva uvjetuje i određenu socijalnu strukturu te gospodarske odnose narednih stoljeća. Budući da je ova zajednica ostala specifična formacija sve do 20. stoljeća, njezina gospodarska osnova je posebno zanimljiva tema kojoj bi vrijedilo posvetiti više pažnje u daljnjim istraživanjima.

Što se 13. stoljeća tiče, razvijenost robno-novčane privrede se odnosi na veće transakcije - naime, do koje mjere su svakodnevne namirnice bile predmet kupnje ili naturalne razmjene nije moguće iščitati iz dokumenata.

Za kraj treba istaknuti još jedan dokument koji nam s drukčijeg aspekta svjedoči o gospodarskim aktivnostima u Turopolju, a posljedica je situacije nastale nakon tatarske provale 1241./1242. godine. Nakon tog događaja, usred nesređene situacije, mnogi su posjedi bili okupirani, a ban Stjepan je dobio nalog od kralja da uvede reda. Okićki knez Ivan Jaroslavić okupirao je dva posjeda i u Turopolju - posjed/zemlju (terra) Odru koja je bila vlasništvo Kurilovih sinova, te šumu turopoljskih plemića. ${ }^{49}$ Ivan i njegovi rođaci su protiv volje turopoljskih plemića u šumu utjerali svoje svinje na ispašu. Ban svim Turopoljcima vraća šumu i naređuje da ona po pravu pripada samo onim plemićima koji su iobagiones castri, te ga ne smiju koristiti ostali pravi plemići kao ni oni koji su de genere servientum regis. ${ }^{50}$ Šuma koja se spominje $\mathrm{u}$ ispravi je zapravo Veliki turopoljski lug. ${ }^{51}$ Ova isprava svjedoči da je svinjogojstvo ekstenzivnog tipa (tzv. "Žirenje") bilo razvijena i očito opće zastupljena aktivnost među turopoljskim plemićima, i šire, budući da se istom stvari bave i rođaci okićkog kneza.

\section{Arheozoološki izvori: rezultati analize životinjskih kostiju}

Za razliku od pisanih izvora, faunalni ostatci su direktan odraz materijalne kulture i u pravilu odraz direktne konzumacije na određenom nalazištu; svjedoče više o konzumaciji negoli o proizvodnji koja je služila za izvoz. ${ }^{52}$ Tako se na identičan način, samo na osnovi faunalne analize, u većini slučaja, ne može se ustanoviti ni je li riječ o uvozu (osim ako se ne radi o nekoj specifičnoj vrsti). Isto tako, kvaliteta i kvantiteta ove vrste izvora ovisi o više faktora koji variraju od nalazišta do nalazišta. Ako se i izuzme faktor same metode istraživanja i pažnje koje određeni istraživač posvećuje prikupljanju kostiju, u obzir treba uzeti prirodne faktore, kao što su

49 Klaić, Povijest Hrvata, str. 372.

50 MHNC 1, str. 8.

51 Laszowski, Povijest plemenite općine, sv. 1, str. 3.

52 Bartosiewicz - Daróczi-Szabó - Daróczi-Szabó - Gál - Kováts - Ljubyanovics, Animal exploitation, str. 20. 
Nikolina Antonić - Kyra Lyublyanovics: Prilog proučavanju gospodarstva i prehrambenih navika... Zb. Odsjeka povij. znan. Zavoda povij. druš. znan. Hrvat. akad. znan. umjet., 34 (2016), str. 21-37

razlike u tlu, koji utječu na proces raspada organskog materijala, divlje životinje koje su razvlačile kosti, uništavanje kasnijim oranjem itd.

Također, rezultate faunalne analize često nije moguće povezati s povijesnim podatcima u smislu da ih s potpunom sigurnošću možemo pripisati ostacima hrane određene društvene skupine. Kada se radi o utvrdama i burgovima to je relativno jednostavno, no sela u ovom slučaju mogu biti problematična. Naime, pojam sela u srednjem vijeku vrlo je širok; većina stanovništva Ugarsko-hrvatskog kraljevstva živjela je na selu, no njihov pravni položaj i imovinska moć bili su različiti. Materijalni ostaci koje će arheologija otkriti ne moraju nužno ukazivati na socijalnu diferencijaciju, pogotovo ako je riječ o rubu mogućeg naselja ili posjeda, odnosno o otpadnim jamama i vatrištima kao u slučaju nalazišta Kobilić 1.

Analizirano je sveukupno 650 fragmenata 407 kostiju. Određivanje vrste bilo je moguće za 217 kostiju, što čini 53.31\% ukupnog broja. Najzastupljeniji su ostaci domaće svinje (Sus domesticus) sa 18.18\%. Zatim slijede ostaci ovce ili koze (Ovis aries, Capra hircus) ${ }^{53}$ s $15.97 \%$, te domaćeg goveda (Bos taurus) s 13.76\%. Od domaćih životinja u malom broju su zastupljene i kosti kokoši (Gallus domesticus) sa $1.47 \%$, te konja (Equus caballus) i psa (Canis familiaris) s 0.98\%. Postotak kostiju divljih životinja je mali, iznosi 3.69\% od ukupnog broja određenih životinjskih vrsta, odnosno $1.96 \%$ od cjelokupnog broja analiziranih kostiju. Zastupljenost kostiju jelena (Cervus elaphus) i srne (Capreolus capreolus) iznosi $0.98 \%$ te $0.74 \%$ od ukupnog broja. Samo jedna kost mogla se pripisati divljoj svinji (Sus scorfa ferus), $0.25 \%$ od ukupnog broja.

\begin{tabular}{|l|l|c|c|c|}
\hline \multicolumn{2}{|l|}{ Vrsta } & Broj & $\begin{array}{c}\text { \% od ukupnog } \\
\text { broja }\end{array}$ & $\begin{array}{c}\text { \% od određenih } \\
\text { broja vrsta (217) }\end{array}$ \\
\hline Domaća svinja & Sus domesticus & 74 & 18.18 & 34.10 \\
\hline Ovca ili koza & Ovis aries ili Capra hircus & 65 & 15.97 & 29.95 \\
\hline Domaće govedo & Bos taurus & 56 & 13.76 & 25.81 \\
\hline Domaća kokoš & Gallus domesticus & 6 & 1.47 & 2.76 \\
\hline Konj & Equus caballus & 4 & 0.98 & 1.84 \\
\hline Pas & Canis familiaris & 4 & 0.98 & 1.84 \\
\hline Jelen & Cervus elaphus & 4 & 0.98 & 1.84 \\
\hline Srna & Capreolus capreolus & 3 & 0.74 & 1.38 \\
\hline Divlja svinja & Sus scorfa ferus & 1 & 0.25 & 0.46 \\
\hline
\end{tabular}

Uz to, pronađena je i jedna kost koja se je mogla identificirati kao ostatak kornjačinog oklopa (Emys orbicularis). Međutim, ova životinja nije ubrojena u identificirane vrste, budući da je teško zaključiti u kojem je vremenskom periodu živjela, te kako su njezini ostavi završili u srednjovjekovnoj jami. Naime, ove životinje se zavlače

53 Kosti ove i koze su vrlo slične. Zbog toga, kada su ostatci fragmentirani kao što je to ovdje slučaj, praktički ih je nemoguće razlikovati, te se svrstavaju u jednu kategoriju. 
Nikolina Antonić - Kyra Lyublyanovics: Prilog proučavanju gospodarstva i prehrambenih navika... Zb. Odsjeka povij. znan. Zavoda povij. druš. znan. Hrvat. akad. znan. umjet., 34 (2016), str. 21-37

u zemlju i hiberniraju tijekom zime, tako da se to moglo dogoditi u bilo kojem periodu nakon što je jama napuštena. No, isto tako treba reći da se ne može potpuno isključiti konzumacija kornjačinog mesa u srednjem vijeku.

Udio neodređenog broja kostiju iznosi 190, što je gotovo polovica sveukupnog broja (46.69\%). Njihova podjela na određene životinjske razrede prikazana je u tablici. Kao što je vidljivo, i ove kosti su najvjerojatnije ostaci goveda ili konja, te svinje, ovce ili koze. Pronađena je i po jedna kost glodavca i vodozemca. Te životinje, kao i kornjača, su mogle u bilo kojem vremenskom periodu ući u jame, te ne moraju imati veze s konzumacijom hrane na srednjovjekovnom nalazištu. Nalazi ostataka glodavaca uobičajeno su prisutni svugdje gdje je bila prisutna pohrana žitarica.

\begin{tabular}{|l|l|c|c|}
\hline \multicolumn{2}{|l|}{ Vrsta } & Broj & \% od ukupnog broja \\
\hline Veliki ungulat & Vjerojatno govedo ili konj & 79 & 19.41 \\
\hline Mali sisavac & & 54 & 13.27 \\
\hline Mali ungulat & Vjerojatno svinja ili ovca/koza & 42 & 10.32 \\
\hline Ptica & Aves ident. & 11 & 2.7 \\
\hline Sisavac & & 1 & 0.25 \\
\hline Glodavac & & 1 & 0.25 \\
\hline Vodozemac & Anura? & 1 & 0.25 \\
\hline
\end{tabular}

Kao što je naglašeno u uvodu, vrijednost materijala u statističkom smislu je minimalna. Koštani ostaci su izrazito fragmentirani, u većini slučajeva se radi o $2-3 \mathrm{~cm}$ velikim ulomcima dijafiza. Nije bilo kostiju dostatnih za izračunavanje visine određene vrste. U ovakvim slučajevima nema smisla ni izračunavanje minimalnog broja jedinki (MNI), tj. ostataka minimalnog broja određene životinjske vrste. Osnova ovog izračuna su određeni dijelovi kostura koji su nađeni, npr. dvije lijeve potkoljenične kosti goveda, očito govore o dva goveda. No, kada su ostaci tako fragmentirani kao u slučaju nalaza s Kobilića 1, nije uvijek moguće ustanoviti jesu li dva mala fragmenta dijelovi iste kosti ili dvije različite kosti. Samim time, svaki je izračun vrlo upitan.

U arheološkom smislu fragmentarnost materijala upućuje na činjenicu da se moguće radi o sekundarnom depozitu materijala. Spiralni lomovi, karakteristični za lomljenje još svježe kosti (uglavnom radi izvlačenja koštane srži) su sporadični, kao i urezi (zamijećeni na svega osam kostiju). Prevladavaju ravni lomovi koji nastaju lomljenjem već osušenih kostiju, gaženjem. Također, na manjem broju ulomaka (njih osam) prisutni su i tragovi životinjski zubi. Dakle, psi (a moguće i svinje) su imali pristup otpadu, koji nije bio spaljen.

Tragovi gorenja uočeni su na 39 ulomaka, a urezivanja na devet. Starost životinje je bilo moguće odrediti u 50 slučajeva. U 19 se radilo o mladim jedinkama (tri kosti goveda, jedna konja, tri ovce ili koze, sedam svinje te pet kostiju novorođene ovce, koze ili svinje). 
Nikolina Antonić - Kyra Lyublyanovics: Prilog proučavanju gospodarstva i prehrambenih navika... Zb. Odsjeka povij. znan. Zavoda povij. druš. znan. Hrvat. akad. znan. umjet., 34 (2016), str. 21-37

\section{Interpretacija nalaza}

\section{a) Domaće životinje - svinja, govedo, ovca/koza, konj, pas, kokoš}

Najveći broj kostiju pripada domaćim životinjama, broj divljih ne prelazi 4\%. Iako je uzorak premali za donošenje bilo kakvih većih zaključaka, može se reći da ovaj rezultat ničim ne odudara od ostalih analiza napravljenih za nalazišta kako Slavonije, tako i Karpatske kotline općenito. Sve ovo su tipične seoske domaće životinje korištene kao izvor hrane, mlijeka, jaja, kože, kosti (upotreba za alatke) te kao radna snaga i prijevozno sredstvo. Istovremeno, bile su i izvor gnojiva. Uzgoj svih vrsta potvrđen je i nalazima sa Šepkovčice. Možda treba naglasiti, s obzirom na to da su ostaci ovce i koze često teško razlučivi, da su se među tim nalazima, zahvaljujući puno većem broju uzoraka, uspjele razlučiti i jedinke ovce i koze. ${ }^{54}$ U Karpatskoj kotlini su ovce i koze obično držane u miješanim krdima, s tim da je broj koza uvijek bio manji. Pravi omjer je, ipak, teže odrediti, zbog sličnosti kostiju ove dvije životinjske vrste.

Također, kosti svinje su općenito najzastupljeniji životinjski ostaci na Šepkovčici (sveukupno u razdoblju od 10. do 15. stoljeća). ${ }^{55}$ Što se Turopolja tiče, ne bi čudilo, s obzirom na podatke iz pisanih izvora, da se i nakon analize svih dostupnih izvora sa svih napravljenih istraživanja, pokaže isti rezultat. I danas je posebna vrsta dlakave svinje tzv. turopolka, zaštitni znak Turopolja, koja se smatra se autohtonom pasminom i jednom od najstarijih vrsta u Europi. ${ }^{56}$

Općenito, na srednjovjekovnim nalazištima Karpatske kotline, svinja, govedo i ovca/koza su najzastupljenije životinje, samo se njihov omjer mijenja. Na mađarskim nalazištima govedo je gotovo uvijek najzastupljenija životinja, a omjer ovce/koze i svinje se mijenja tek tijekom 13. stoljeća u korist svinje, što se ponekad objašnjava dolaskom naseljenika (uglavnom njemačkog porijekla) te uvođenjem novih prehrambenih navika, kao i potpunim prihvaćanjem sjedilačkog načina života među mađarskim stanovništvom. ${ }^{57}$ Naravno, važan faktor je i okoliš: za ovce su pogodni veliki pašnjaci na otvorenom, dok svinje preferiraju močvarna i šumovita područja.

Uz Kobilić i Šepkovčicu, na još je nekoliko naših nalazišta zabilježena veća zastupljenost svinjskih od goveđih kostiju. Takva je situacija ustanovljena na nalazištima u Torčecu za slojeve od druge polovice 10. do 14. stoljeća. Budući da su ovo bila i prva sustavna istraživanja i analize na našem području, autori, $u$ analizi faze Torčec IV (druga polovica 10. - poč. 12. st.) i sami ističu da na ostalim mađarskim i rumunjskim lokalitetima nigdje nije zabilježena tolika prevlast svinje. ${ }^{58}$ Prevlast svinje

54 Bugar, Naselje ranog srednjeg vijeka, str. 180.

55 Na ist. mj.

56 Marija Đikić, Ivan Jurić, Povijest istraživanja o turopoljskoj svinji, u: Turopoljska svinja - autohtona hrvatska pasmina, ur. Marija Đikić - Ivan Jurić - Franjo Kos, Velika Gorica 2002., str. 41-46.

57 Bartosiewicz - Daróczi-Szabó - Daróczi-Szabó - Gál - Kováts - Lyublyanovics, Animal exploitation in Medieval Hungary, str. 24

58 Kužir -Trbojević-Vukićević - Poletto, Životinjski ostaci, str. 349. 
Nikolina Antonić - Kyra Lyublyanovics: Prilog proučavanju gospodarstva i prehrambenih navika... Zb. Odsjeka povij. znan. Zavoda povij. druš. znan. Hrvat. akad. znan. umjet., 34 (2016), str. 21-37

zabilježena je i na nizinskom gradištu Torčec Gradić (13.-15. st.). ${ }^{59}$ Još je zanimljivije da je ista situacija i u svim slojevima od 12. do 14./15. st. na tvrdom gradu Vrbovcu. ${ }^{60}$ Ostala dosad obrađena naša nalazišta pokazuju prevlast goveda, no ona su ili gradišta i utvrde nešto kasnije datirana od 13. stoljeća. ${ }^{61}$

Zanimljiva su razmatranja što ih je iznio već Bökönyi šezdesetih godina prošlog stoljeća. On je smatrao da prevlast svinje ima veze sa slavenskom populacijom koja je u velikom broju preživjela mađarsko osvajanje. ${ }^{62}$ Slično piše Bartosziewicz: "na mnogim močvarnim i šumovitim dijelovima Karpatskog bazena, gdje je ova tradicija postojala stoljećima prije dolaska Mađara, svinjogojstvo je zadržano kao osnovna grana privrede kroz cijeli srednji vijek". ${ }^{63}$ Ipak, pitanje ostaje je li ovo samo stvar prirodnog okoliša ili i tradicije. Vjerojatno je odgovor: oboje.

Na nekim nalazišta u zapadnoj Transdanubiji (Csatár, Dombóvár, Zalavár-Vár) zabilježen je veći broj ostataka svinje u odnosu na ostatke goveda (nalazišta su datirana u period 10.-13. st.). ${ }^{64}$ Poput Kobilića, i ovdje se radi o manjem broju nalaza, te se može reći da oni pokazuju generalni trend. Također, veći broj ostataka svinje zabilježen je i na nekim nalazištima u sjeveroistočnoj (Mátraszőlős-Kisvár i Mende) te jugoistočnoj Mađarskoj (Szarvas - Rózsás), ${ }^{65}$ gdje je također okoliš pogodan za svinjogojstvo.

U svakom slučaju, u kolikoj je mjeri značajna tradicija a u kolikoj okoliš, pokazat će daljnja istraživanja. Za razliku od svinje koja se koristi kao izvor mesa te se ponekad i upotrebljava svinjska koža i dlaka za četke, isplativost goveda je višestruka: uz meso i kravlje mlijeko, ono se koristi za vuču, kožu, kosti, gnojenje zemlje. Klanje mladih goveda, dakle držanje goveda samo zbog mesa, predstavljalo je, u neku ruku, luksuz.

Jedna isprava iz 1293. koja se odnosi na ivanovački, čičanski, preceptorat može nam donekle dati okvir vrijednosti stoke u odnosu na zemlju. Između ostalog, iznosi da su naseljenici (hospites) dužni jednom godišnje davati jednu junicu ili 40 denara, tri bačve vina, sto kruhova i šest kokoši. ${ }^{66}$ Možemo tako pretpostaviti da je jedna junica vrijedila 40 denara, odnosno jednu pensu. Kada je Miroslav 1260. kupovao

59 Kužir - Trbojević-Vukičević, Životinjski nalazi, str. 119. Iako slično kao i na Kobiliću, rezultati za svinje i goveda su vrlo blizu (66:64).

60 Trbojević-Vukičević - Frančić - Kužir, Analiza životinjskih kostiju, str. 236-244.

61 Treba spomenuti da i je i analiza kostiju iz nizinskog naselje na lokalitetu Josipovac Punitovački-Veliko Polje I, pokazala puno veću zastupljenost goveđih kostiju, no kao što sami autori ističu, ovdje se radi o malom broju uzoraka (151) iz srednjovjekovnog horizonta. Trbojević-Vukičević, Govedo - osnova stočarstva, str. 283

62 Sándor Bökönyi, The Development and History of Domestic Animals in Hungary: The Neolithic Through the Middle Ages, American Anthropologist, sv. 73, br. 3, 1971., str. 663.

63 Bartosziewicz, Animal husbandry, str. 146.

64 István Vörös, Adatok az Árpád-kori állattartás történetéhez [Bilješke o držanju životinja u Ugarskoj u doba dinastije Arpadovića], u: A középkori magyar agrárium. Tudományos ülésszak Ópusztaszeren. [Srednjovjekovna ugarska agrikultura. Znanstvena konferencija u Ópusztaszeru], ur. Lívia Bende - Gábor Lőrinczy, Ópusztaszer 2000., str. 71-120.

65 Vörös, Adatok az Árpád-kori állattartás, str. 81.

66 CD 7, str. 133-135. 
Nikolina Antonić - Kyra Lyublyanovics: Prilog proučavanju gospodarstva i prehrambenih navika... Zb. Odsjeka povij. znan. Zavoda povij. druš. znan. Hrvat. akad. znan. umjet., 34 (2016), str. 21-37

zemlju, platio je 12 vretena zemlje 15 pensi. ${ }^{67}$ Jedan vremenski bliži dokument iz 1276. govori o prodaji 10 vretena zemlje za 10 pensi banskih denara. ${ }^{68} \mathrm{U}$ ispravi ivanovaca ne precizira se o kojoj moneti se radi, no budući da se radi o Slavoniji, sigurno su u pitanju banovci, pa možemo okvirno reći da je jedna junica vrijedila kao $1-1,5$ vretena zemlje. Na žalost, s obzirom na to da su srednjovjekovne mjere lokalne i da vreten za ovo područje nije preračunat, ne znamo koliko je zapravo iznosio te o kojoj veličini zemlje se radi. ${ }^{69}$

\section{b) Divlje životinje - srna, jelen, divlja svinja}

Rijetki ostatci divljači, odnosno srne, jelena, te jedna kost divlje svinje, upućuju na povremeni lov kao dodatni izvor prehrane. Neki koštani ulomci jelena, kao nadlaktična kost (humerus) i palčana kost (radius) ukazuju da je ulovljena životinja cijela donesena u naselje (za razliku od tzv. Shlepp-effekta kada se meso skida s kostiju odmah kada je životinja ulovljena, te se meso životinje zamata u kožu i odnosi).

Mali postotak divljači uobičajena je pojava na seoskim nalazištima, kako na mađarskim, ${ }^{70}$ tako i na našim. Obično je postotak nešto viši na tvrdim gradovima (5-7\%). Nestašica divljih životinja obično se objašnjava zabranom lova koje je zabava rezervirana za plemstvo, iako zapravo za razdoblje 13. stoljeća te regulacije nisu potpuno jasne. Što se Turopolja tiče, s obzirom na socijalnu strukturu, pitanje je koliki je broj ljudi imao pristup lovu. Iz isprave bana Stjepana iz 1249., u kojoj on Turopoljcima vraća njihovu šumu, jasno je da je ta šuma zajedničko, komunalno vlasništvo. Samim time dakle što u Turopolju nema jednog vlastelina koji postavlja uvjete te koristi šumu kao svoje vlasništvo, već više sitnih plemića koji imaju jednaka prava i udjele u zajedničkim dobrima, vjerojatno i više ljudi ima pravo na lov. No, zbog očuvanja prirodne ravnoteže, za pretpostaviti je da su neke regulacije postojale između samih plemića, iako o tome nemamo sačuvanih dokumenta.

Uz to, nije se radilo samo o prostoru Velikog turopoljskog luga; veliki dio površine u Turopolju pokrivale vlažne šume i močvare. O tome i danas svjedoče brojni toponimi. Na primjer, prvotno značenje riječi Gorica kao deminutiv od Gora je bilo brdo, a zatim i šuma te vinograd. ${ }^{71} \mathrm{~S}$ obzirom na to da je Velika Gorica smještena u ravnici (u Polju, kako se ravničarski dio Turopolja zove), ovdje se najvjerojatnije radi-

67 MHNC 1, str. 16-17.

68 MHNC 1, str. 29-30.

69 Postoje međutim etnografski podatci koji mogu pomoći u daljnjem istraživanju. Prema objašnjenju gosp. Slavka Stepanića (kojemu zahvaljujemo) zemlja se u selu Donja Lomnica tradicionalno označavala na sljedeći način: širina zemlje koju zahvaća jedan plug se zvao brazda. Nakon šest brazdi napravio bi se jarak, a ta mjera bi se zvala slog (dakle širina šest brazdi). U svojoj knjizi Plemeniti puti, izdanoj prvi put 1952., Vojko Miklaušić je zapisao da je jedan slog jednak šest brazdi i tri vretena. To bi značilo da je jedno vreteno bilo široko kao dvije širine pluga. Vojko Miklaušić, Plemeniti puti, Donja Lomnica 1994., str. 150.

70 Općenito je u mađarskim selima postotak divljači vrlo nizak, oko 2\%: Bartosiewicz - Daróczi-Szabó Daróczi-Szabó - Gál - Kováts - Lyublyanovics, Animal exploitation in Medieval Hungary, str. 25.

71 Petar Skok, Etimologijski rječnik hrvatskoga ili srpskoga jezika, sv. 1, Zagreb 1971., str. 589-590; Rječnik hrvatskog ili srpskog jezika, sv. 3, ur. Pero Budmani, Zageb 1887.-1891., str. 270-272, 283. 
Nikolina Antonić - Kyra Lyublyanovics: Prilog proučavanju gospodarstva i prehrambenih navika... Zb. Odsjeka povij. znan. Zavoda povij. druš. znan. Hrvat. akad. znan. umjet., 34 (2016), str. 21-37

lo o šumi. Ime sela Hrašće je množina riječ hrast, ${ }^{72}$ te upućuje na postojanje hrastove šume. S druge strane, imena sela Velika i Mala Mlaka, znače močvara, bara ili lokva. ${ }^{73}$ Također, u opisima granica posjeda koje nalazimo u kupoprodajnim isprava ova je riječ vrlo često korištena. Turopolje je dakle imalo idealan okoliš kako za ekstenzivno svinjogojstvo (tzv. žirenje) tako i za lov. Ne treba zaboraviti ni važnost hrastovih šuma kao građevinskog materijala. Zanimljivo je spomenuti jednu ispravu iz 1269. godine. Herceg Bela je svrgnuo Staniška, sina Waracyska, i cijeli njegov rod, koji su dotada imali status plemića (iobagiones castri) na niži rang gračana (ex inde in castrenses idem dominus dux Bela eosdem redegisset). Njihova je dužnost bila nošenje drva (in delaturam lignorum, sew ligniferos condicionarios indicissent). Kasnije ih je ban Joakim ponovo uzdigao u red iobagiones castri, a to je potvrdio i kralj Stjepan V. ${ }^{74}$

\section{c) Ribolov}

Na kraju, kao posebnu dopunsku aktivnost treba spomenuti i ribolov. Nalazi ribljih kostiju nisu prisutni na nalazištu Kobilić. No, riblje kosti su vrlo sitne i rijetko se očuvaju i pronađu u iskopavanjima. ${ }^{75}$ Da je u Turopolju ipak bilo prisutno i jedenje ribe potvrđuje nalaz dva nalaza kosti sa Šepkovčice. ${ }^{76}$ Isto tako, u ispravi iz 1267. $\mathrm{u}$ opisu međa posjeda/zemlje (terre) Conchan spominje se i piscina, ${ }^{77}$ no ne kao dio standardne formule prisutne $\mathrm{u}$ ispravama od 14. stoljeća na dalje, već kao fizički, stvarni opis granice. No, i ovo je zapravo logično - Turopolje je bilo puno malih potoka i zaostalih rukavaca Save, koji su zasigurno bili bogati ribom.

\section{Zaključak}

Srednjovjekovni razvitak Turopolja je specifičan, ne samo u okvirima srednjovjekovne Slavonije, nego i Hrvatsko-ugarskog kraljevstva općenito. Društvena i pravna povijest ove regije bile su predmetom razmatranja više studija, no ekonomskoj povijesti Turopolja, i njenoj mogućoj mijeni kroz stoljeća, nije posvećeno toliko pažnje. Što se perioda formiranja ove zajednice tiče, dakle perioda 12. i 13. stoljeća, povijesno istraživanje je otežano u prvom slučaju nedostatkom, a u drugom malim brojem izvora.

Ovim člankom pokušalo se dati mali doprinos te novi pogled ovom pitanju i daljnjim mogućnostima njegovog rješavanja, kombiniranjem podataka iz različitih vrsta

72 Skok, Etimologijski rječnik, str. 684-685; Laszowski, Povijest plemenite općine, sv. 1, str. 332; Hrvatski enciklopedijski riječnik, ur. Ljiljana Jojić, Zagreb 2004., str. 450.

73 Tomislav Ladan, Život riječi: etimologija i uporaba, Zagreb 2009., str. 213-214; Alemko Gluhak, Hrvatski etimološki rječnik, Zagreb 1993., str. 416; Dunja Brozović-Rončević, Nazivi za blatišta i njihovi toponimijski odrazi u hrvatskome jeziku, Folia onomastica Croatica, sv. 8, Zagreb 1999., str. 39; Skok, Etimologijski rječnik, sv. 2, str. 440 .

74 MHNC 1, str. 24-27.

75 Zato je potrebno provoditi postupak tzv. "mokrog sijanja".

76 Zdravka Hincak - Damir Mihalić, Izvješće - Osteološka analiza animalnih ostataka s nalazišta Šepkovčica, Zagreb 2010.

77 MHNC 1, str. 22. 
Nikolina Antonić - Kyra Lyublyanovics: Prilog proučavanju gospodarstva i prehrambenih navika... Zb. Odsjeka povij. znan. Zavoda povij. druš. znan. Hrvat. akad. znan. umjet., 34 (2016), str. 21-37

izvora. Povijesni dokumenti jasno svjedoče o zemlji koja je kao privatno vlasništvo bila predmet transakcije te o moneti koja je bila u upotrebi. Također iz njih se može iščitati da je ekstenzivno svinjogojstvo bila razvijena gospodarska grana (posebice ispaša svinja u šumama). No, s druge strane, goveda se puno rjeđe spominju, a ovce ili koze nikad. Uz to, i nalazi divljači i toponimi ukazuju na rasprostranjenost šuma na turopoljskom području. Isprava o Stanišku i njegovu rodu postavlja pitanje u kolikoj je mjeri bila zastupljena trgovina drvetom.

Broj ostataka hrane, tj. životinjski ostatci, s nalazišta Kobilić 1 sam je po sebi premali za bilo kakve zaključke. On može poslužiti samo za ilustraciju, u smislu ukazivanja na neka nova pitanja. No, sustavnim prikupljanjem podataka bit će moguće napraviti veće baze podataka, koje će pokazati u kolikoj je mjeri bilo zastupljeno svinjogojstvo, stočarstvo ili lov. Iako, kao što je rečeno, ovi ostaci u pravilu predstavljaju direktne ostatke hrane i svakodnevne konzumacije, a u određenoj mjeri oni svjedoče i o ekonomskoj osnovi nekog kraja. U tom smislu potencijali koje arheozoologija nudi daljnjem razvoju medievistike su veliki. Daljnjim objavljivanjem rezultata s istraženih nalazišta baza podataka će se povećavati, a time i mogućnost za nove spoznaje o svakodnevnom životu i gospodarskoj osnovi turopoljskog sela. 
Nikolina Antonić - Kyra Lyublyanovics

\section{A Contribution to the Research of the Economy and Dietary Habits in Turopolje in the Thirteenth Century. Animal Remnants from the Archaeological Site of Kobilić 1}

Summary

This paper tries to raise some questions and offer some new insights into one, hitherto neglected, topic: the economic basis of the castle warriors of Turopolje in the thirteenth century. Two types of sources were used in this analysis: historical sources - thirteenth-century charters from Turopolje - and archaeozoological sources - faunal remains from the archaeological site Kobilić 1. Although the number of the faunal remains collected during the excavations at Kobilić 1 is too small to allow any far-reaching hypothesis and conclusions, the paper argues that even this small amount of data has a certain value when incorporated into the frame of a certain region. While charters inform us about the private ownership of the land, about the land as a frequent object of sale (with the Zagreb denarius being the money in use in this period), and about extensive pig farming and the group of castrenses whose duty was to carry wood, the animal remains point to some activities, such as hunting and the raising of sheep and goats, that are not mentioned in the sources. With the systematic publication of the archaeozoological results, the data will increase, and new and more precise conclusions about both the economic basis and the everyday life in Turopolje in the Middle Ages will be offered. In that respect, the potentials of archaeozoology in the further development of medieval studies are significant, especially for the earlier centuries, when there are no written documents or only a small amount. Along with that, some methodological problems that researchers face in terms of connecting the archaeological remains with a specific social group are also discussed, through the example of the site Kobilić 1.

Key words: Turopolje, Kobilić, castle warriors, castrenses, historical sources, archaeozoological sources 